\title{
Teaching Contemporary Art in Primary Schools
}

\author{
By Chor Leng Twardzik Ching*
}

This paper proposes that educating students in Contemporary Art is essential in the 21st century classroom. In this global climate, being able to understand and translate visual data is vital to one's ability to navigate through a complex world. The ability to understand visual 'language' is a teachable skill that can empower the classroom teacher to likewise enable their students in creative and critical thinking. One of the most challenging tasks an art teacher faces in today's classroom is to explain the meaning behind art that is sometimes deemed as too vulgar, meaningless or shocking. Understanding the historical context of the work, appreciating the reasons for its creation, articulating their significance and participating in the art making process, help students gain confidence in their own ability. Contemporary art in the classroom, because it encourages these skills, becomes an aid to encourage higher-order thinking, problem solving and deep reflection. Art educators who are empowered with a broad knowledge of contemporary art and culture, who have an understanding of the link connecting art of the past and contemporary art, and a renewed appreciation of the importance of art education, are better able to bring art education in primary schools beyond step-by-step activities. This paper will explore the benefits of teaching contemporary art to children in primary schools and will debunk the myth that contemporary art is beyond the cognitive abilities of these children. The challenging nature of many contemporary artworks and ideas can be used to stimulate the curiosity that is natural in children and imparts an understanding of art as a whole.

\section{Introduction}

This paper will explore the feasibility and possible benefits of teaching contemporary art to children in primary schools aged between 7-12 years old. The Advanced Diploma in Primary Art Education in The National Institute of Education, Singapore (NIE) was developed for primary school teachers who are non-art trained but have been tasked to teach art. A survey was sent out to these teachers after the course to evaluate its efficacy, if they have started introducing contemporary art to their students, and if there are any observed benefits to teaching contemporary art. This paper concludes by examining the

${ }^{*}$ Lecturer, National Institute of Education, Singapore. 
challenges and possible benefits of teaching contemporary art practices in primary schools.

\section{The Role of Contemporary Art within Art Education}

The confusion with the seeming disappearance of older traditions and ideas in the wake of contemporary art has spilled over into the field of education and has affected the teaching of art in the classroom detrimentally. When "is this art?" is the first question that most viewers ask when they see an art exhibition, then teachers who do not have an answer to this query often become unwilling to teach it as art in the classroom because they are simply not sure if what they are teaching is art. If educators are not confident about their subject matter they may avoid teaching it by substituting challenging material with lessons they perceive to be more age appropriate or more in line with desired outcomes.

In order to empower teachers in the classroom in the teaching of art, they must first understand art, more specifically they must recognize contemporary art and grapple with its significance.

\section{Art Syllabus versus Classroom Practice}

The "Aims of Art Education" according to the "Art Syllabus: Primary and Lower Secondary" document in 2008 outlines the goal that are to guide curriculum planning:

"The aims of art education are to enable every child to be visually literate and to appreciate art. Visually Literate:

- Being visually literate, our students are able to observe, understand and make meaning of what they see. They are also able to communicate their ideas by using and creating visuals. Appreciate Art:

- Students will be able to see the value and recognise the relevance of art in their lives."

(Singapore Ministry of Education (CPDD), 2008, p.2)

Written syllabuses despite good intentions often remain documents with little sway over what is actually being taught in schools. More often than not, students are trained to stick to conventional approaches and techniques such as those employed in representational drawing and painting or handicraft. These conventional approaches come with equally conventional assessment modes resulting in a stifled form of creative environment in the classroom where artworks or ideas that cannot be easily quantified according to the assessment criteria, are rejected or discouraged. 
"the accountability culture is pervasive, undermines trust in teacher professionalism and encourages a sense that there should be a tangible product or outcome from educational endeavour."

(Hall, Thomson, \& Russell 2007, p.615)

Art teachers' professionalism is in part assessed by the school management by the quality of student art exhibitions. This often pressures them into creating 'product based' art exhibitions not for the benefit of the student but for fulfilling the expectations of school management and parents regardless of the relevance of these expectations to art learning and any associated benefits. The resulting student artworks although seemingly technically advanced and of a certain aesthetic standard are often creatively bankrupt and necessarily limited. Although such an art education, however traditional, is better than none, a prescriptive art education may be damaging to the creative, experimental and artistic development of a child. As Ken Robinson has aptly pointed out:

"If you're not prepared to be wrong, you'll never come up with anything original...And by the time they get to be adults, most kids have lost that capacity. They have become frightened of being wrong...And the result is, we are educating people out of their creative capacities.

Picasso once said this, he said that all children are born artists. The problem is to remain an artist as we grow up. I believe this passionately, that we don't grow into creativity, we grow out of it. Or rather we get educated out of it." (Robinson, 2006)

The lack of understanding the value of art and arts education by teachers and administrators is an issue that should be addressed through further research in an effort to ensure that the benefits associated with the arts are effectively gained and experienced by students in their primary and secondary education.

\section{Introducing Conceptual Art}

Conceptual Art, as an example within the context of Contemporary Art is an intriguing and engaging topic to introduce to primary school students. It is an art movement that did not fit any criteria that existed at the time it was created, but has had a lasting influence on contemporary art. At its peak in the 1960's, the concept of an artwork began to take precedence over its visual or aesthetic concerns (Godfrey, 1998). It first gained notoriety for being controversial and for challenging existing assumptions and authorities in art. Conceptual art is an example that clearly illustrates the dichotomy between teaching contemporary art and the current practice in the classroom (Cheo \& Millan, 2012, p. 20). And who better to illustrate this than Marcel Duchamp, considered by many to be the father of Conceptual Art. 
Duchamp made headlines in the art world, not for making 'traditional' paintings but for challenging the existing art world. He set out to question several assumptions, 'What is art?' and 'Who has the authority to decide what is art?' The Society of Independent Artists was having an exhibition and the only criterion for entering work into the show was simply for each artist to pay $\$ 6$. He then went about to test this seemingly democratic criteria by entering the infamous 'Fountain', 1917, an overturned urinal, under the pseudonym R. Mutt. As it turns out, 'Fountain' was rejected despite the fact that it had fulfilled the only criteria of the $\$ 6$ payment (Godfrey, 1998).

Conceptual Art is controversial mainly because it constantly pushes the boundaries of what art is or can be, causing the mother of all questions in the art world, 'What is Art?' This question is both a form of self-critique and selfrenewal and is a double edged sword. On the one hand it devalues what art had been defined as up until its arrival, on the other it liberates art from what it ought to be, allowing artists to create in a more exploratory way in all genres.

Teachers would clearly not have much difficulty engaging students through conceptual art with its 'question everything' attitude having so much in common with children's natural curiosity. By introducing conceptual art to the students, they can start to see their own rebellious or unconventional thinking is not necessarily negative and if channeled into art making, can be an extremely powerful, self-reflexive experience. In this learning process, experiencing specialized lectures, studio work, museum visits and art discussions may help students to contextualize their learning and their own thoughts. Through gaining visual literacy and communication skills, contextual understanding and critical thinking skills, contemporary art in the classroom becomes an aid to encourage higher-order thinking, problem solving and deep reflection (Gallavan, Webster-Smith \& Dean, 2012). Empowered with a broad knowledge of contemporary art and culture, understanding of the link connecting past art and contemporary art, and a renewed understanding of the importance of art education, teachers can bring their passion to teaching the value of the arts to our future generations.

\section{Advanced Diploma in Primary Art Education in the National Institute of Education (NIE), Singapore}

The Advanced Diploma in Primary Art Education in NIE is a 16 week full time in-service course developed for primary school teachers.

This programme is designed:

- To provide teachers with a framework of knowledge and skills in art that will be useful in their roles as classroom teachers as well as practitioners.

- To provide perspectives on the change and development of theories and trends in art and art education for teachers to 
reflect, re-examine and to draw inferences about their classroom practices.

- To enable teachers to develop competencies in the evaluation and planning of effective art curriculum and programme in their schools" (NIE website 2014)

Modules include hands on art making components, art pedagogy, art history and art theory. Students engage in hands on art making processes and lectures where contemporary art history and theory is introduced. Contemporary art is introduced through broad categories such as Conceptual Art, Installation Art and Land Art including artists such as Marcel Duchamp, Joseph Beuys, Antony Gormley, Christo \& Jean-Claude, Mona Hatoum and Montien Boonma. They are then tasked to exhibit an artwork conceived either through individual or group endeavor at the end of the course (figure 1). Students are encouraged to push the boundaries beyond traditional art making practices that they are accustomed to and engage in unfamiliar, contemporary art making practices such as Installation Art and Conceptual Art. A group critique of the exhibited artworks serves to conclude the course. At this point, discussions of the possible benefits of the course and its adaptability in primary school curriculums are debated. This course has been offered 6 times in the last 3 years from 2011 till today. A survey (refer to appendix) was sent out in February 2014 to ask for their feedback on the impact the course has had on their current practice as art teachers and the influences it has had on their art curriculums, and in turn the impact that has had on their students.

Figure 1. Cast Figure Placed Above the NIE Art Gallery Done by StudentTeachers During the Advanced Diploma Course in Response to Mark Jenkins' Figurative Interventions

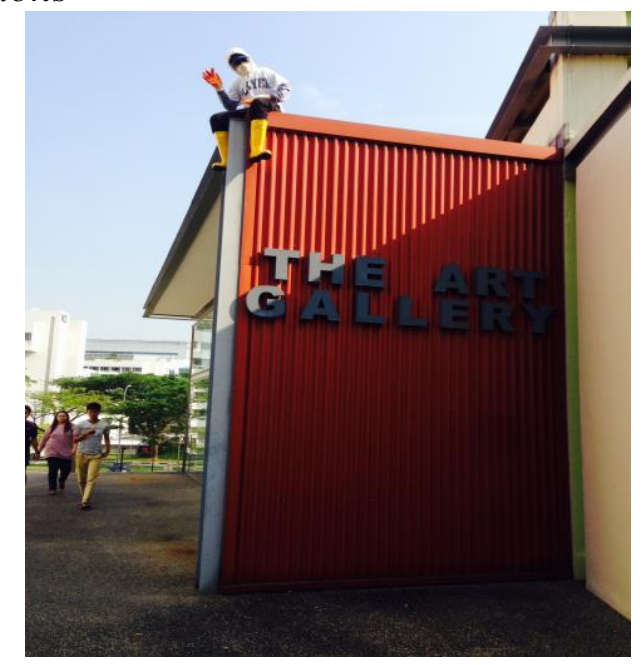

This survey was sent out to 105 participants, 13 responded. The following is a sampling of some of the most significant responses. 


\section{Survey Results}

Understanding of Contemporary Art before Taking the Advanced Diploma Course

Question:

How did you feel about Contemporary Art before embarking on the Advance Diploma course?

Answers:

Limited Knowledge of Contemporary Art

- I have very limited knowledge about contemporary art...

- I did not have knowledge of contemporary art at all

- Did not know much about it and were more focused on master artists and making realistic drawing and paintings

Limited Understanding of Contemporary Art

- Could not understand why some of them are called art and put in museum

- I felt that contemporary art was something quite difficult to understand. I had seen a lot of strange installations at the Singapore Biennale and wondered how some of them could be labeled art for they were not aesthetically appealing to me

- Abstract and difficult to comprehend

Understanding of Contemporary Art after Taking the Advanced Diploma Course

Question:

How did you feel about Contemporary Art after the Advanced Diploma course?

Answers:

More In-Depth Knowledge About Contemporary Art

- I have more in-depth knowledge about contemporary art so I am able to select suitable artists to talk about in class

- I had a better idea and am able to incorporate what I have learnt into my art syllabus in school

- A clearer picture of what defines Contemporary Art

- The course was very insightful. I got to know more about what is Contemporary Art and the artists associated with it. It has piqued my interest in finding out more about contemporary art

- I find that I am not so 'scared' of it anymore Appreciation for Contemporary Art 
- The course helped me to have an appreciation for contemporary art because I began to see that most of the contemporary artists are very passionate about their art

- Interesting and I feel I could relate to the artists and their viewpoints better. Set me thinking "why didn't I think of that?". I feel "liberated" for the artists. I also admire the artists for making very bold and strong statements through their artworks

- I feel more connected, like the stories being shared, the history behind, the present, modern art, and appreciate Contemporary Art more

- Inspiring

The responses seem to indicate that before the Advanced Diploma course, most of the participants had "limited knowledge" or "did not have knowledge of contemporary art at all" and viewed contemporary art as "Abstract and difficult to comprehend". Their art making repertoires "were more focused on master artists and making realistic drawing and paintings". After the Advanced Diploma course, they have "a clearer picture of what defines Contemporary Art", "a more in-depth knowledge about contemporary art" so they are "able to select suitable artists to talk about in class" and they are "not so 'scared' of it anymore", to the point where "It has piqued (their) interest in finding out more about contemporary art". The responses seem to indicate that the Advanced Diploma course has had a noticeable impact on their understanding of contemporary art and more importantly, their interest in art as a subject increased and so did their confidence in teaching the subject as well.

\section{Challenges/Reservations}

What is of specific interest is whether they applied what they have learnt in their school curriculum.

Question:

Have you introduced any of the above topics to your students in school? Yes/No

Of the 13 respondents, 10 have introduced contemporary art to their students in school and 3 have not. Of the 3 who have not introduced the topic, one said that it is because he had to "follow school SOW (Scheme of Work)" and the other thought that "at their young age (Primary Level) they should know about EOA/POD (elements of art/principals of design) before they go into conceptual art. Maybe at secondary level it will be more suitable".

This finding is important as it shows that teachers still have reservations in introducing the topic of contemporary art because they do not think that it fits into their Scheme Of Work and that it was too 'conceptual' for students at a young age. The teaching and learning of EOA/POD, also understood as a more formal/aesthetics based art education, is seen to be of more value in primary art education. 
Creative production in contemporary art practice may have none of the homogenising characteristics commonly found in school practices, and may instead be revered for features in direct opposition to those necessary for regulative assessment, in that they may be collaborative and heterogeneous and subversively critical, and lacking in any tangible object or even the residue of an event.

(Adams 2010)

What is apparent is that the emphasis in school art is still formal and object based. However, more investigation will be needed to fully understand the difficulties faced in introducing contemporary art in primary schools in Singapore.

Introducing Contemporary Art in Primary Art Classrooms

Of the 10 respondents who did introduce contemporary art to their students, here are some examples of how they introduced it:

Question:

How did you introduce the topic of Contemporary Art to your students? Is it through hands on art making sessions, field trips, slide presentations or otherwise? Please give specific examples if any.

Answers:

Introducing Contemporary Art through Field Trips

- I took my art club pupils (43 of them, Pri 3-Pri 6) to the AEP exhibition at Zhonghua Secondary School on 7 March this year. They had several art installation pieces. Mr Liong Huai Yu, the teacher-in-charge of the AEP exhibition, conducted a brief discussion on one of the art pieces. I had also briefed my pupils and provided the following questions for them to think about and discuss in their teams of 2-4 pupils. They also took photographs using the school's tablets. Questions posed: What do you see on the piece of work? (Describe the work).

What do you think the artist is trying to say?

What clues do you find on the art work to inform you?

Describe how this work makes you feel.

Why does it make you feel this way?

- Field trips - Aesthetic camp is held every year during March holiday and I took the chance last year to introduce installation art as that was some part of the exhibition held at SAM and $8 Q$ (museums that showcase mostly contemporary artworks in Singapore) during those few months 
Introducing Contemporary Art through Art Talks/Slide Presentations

- I gave a brief talk about it during an assembly slot in school where I introduced pupils to Land Art. The P3 pupils have a learning journey to Singapore Art Museum to learn more about contemporary art through the Junior Artists program

- Slide presentation on artworks that are contemporary

Introducing Contemporary Art through a combination of New Lesson Approaches, Slide Presentations, Field Trips and Art making

- Abstract expressionism was introduced to the students. Pupils were introduced to colours (primary, secondary, tertiary) first in lower primary and through the activity of drip painting (given only primary colours), pupils were made to observe and describe the final product in subsequent lessons (Feldman's approach: Describe). Then, the artist Jackson Pollock is introduced with PPT slides. On a separate note, Art club pupils went on a learning journey to Lasalle to view the work of Art Elective Programme (AEP) students.

- I have used storybooks to teach polka-dot art. For example, the storybook on Alice's Adventures In Wonderland,' as Illustrated by Yayoi Kusama is used to teach the students about the unique style of how dots can be incorporated into the drawings as illustrations for the settings in that storybook. Art appreciation sessions are incorporated into the discussions for students to raise their queries pertaining to the artist's intention on creating such art form.

- My school engages the Art outreach programme which includes a few portfolios on land and environmental art.

- Share with them about Art Installation... got students to make origami, and ask them to display.

The results indicate that they employed different strategies in teaching the students about contemporary art. Slide lectures feature quite prominently as well as art discussions, "Art appreciation sessions are incorporated into the discussions for students to raise their queries pertaining to the artist's intention on creating such art form". There were also field trips to museums that feature contemporary art works and collaborations to visit secondary schools to look at how they conduct their art programmes as teachers see the importance of connecting the primary art syllabus to the secondary art syllabus. Involving the students in less traditional art making processes that includes getting them to display the work themselves after having introduced topics such as Installation Art allows the child to have creative autonomy over not only their own artworks but also the learning space that they inhabit (figure 2). 
Figure 2. An Art Installation of Origami Boats Done by Primary School Students. Their Art Teacher was a Participant in the Advance Diploma Programme and one of the Survey Respondents

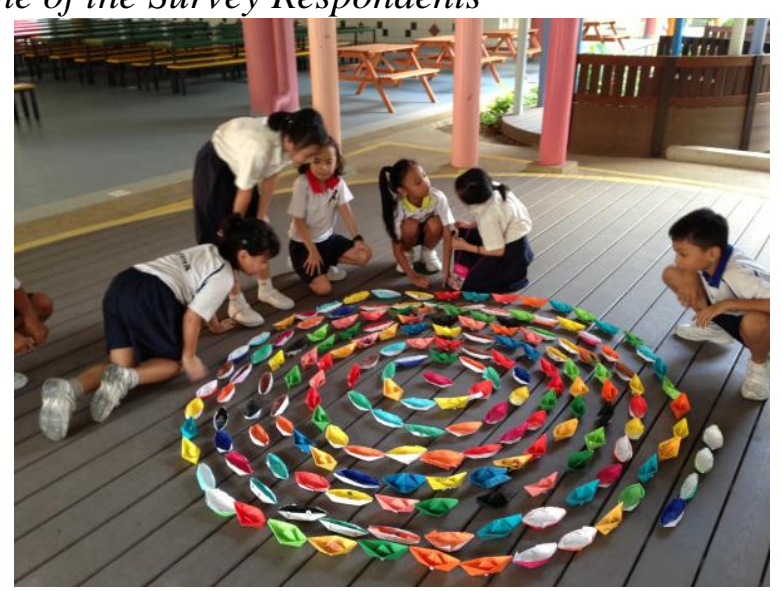

Finally, the benefits of introducing contemporary art into their art syllabus:

\section{Benefits}

Question:

How did teaching them to make contemporary art/introducing them to contemporary art benefit the students? Please give specific examples if any.

\section{Answers:}

\section{Engaged Learners}

- ... we took 3 periods (1 1/2 hrs) for pupils to share their views and I was really pleasantly surprised that they were all so thoroughly engaged in the discussions.

- My current P6 class started off with very little interest in art and does art work in a mundane, meaningless manner. As their socalled 'not great' artworks were slowly being affirmed, I started to observe more varied designs and thinking in their subsequent artworks.

- Some came up to ask more questions and jotted down names and keywords so that they could go back home to do more research.

Pupils are more aware of other art forms and think out of the box. It is also a great opportunity to introduce them to the term 'perspective' and teaching them how to think in different perspectives or think of questions in different ways or from different directions.

Freedom of Expression and Empathy through Art

- My art club pupils have learned that an art piece evokes different feelings and opinions in different people. 
- The open discussions have helped to broaden the views of my pupils. They have learned to express their views and not be afraid to say them and then justify them with reasons.

- I feel that it better engages them in that an art piece need not be neat, nicely coloured although all of that is part of art. It brings them through the thinking process about what really is art and how they can express themselves better through art.

- Students are more receptive to their peers' artwork and they are willing to try to see from the perception of an artist's view. They are also observed to be more aware of understanding the intent taken in creating certain art form than to give instant criticisms on the visual representations.

\section{No Limit to Creativity}

- ...they also realized there is no right or wrong answer.

- Pupils realized there's no limit to creativity. Pupils were amazed and they could not quite understand that "art" can be so extreme and abstract.

- The pupils became more aware of the concept of art and creativity. Most of the pupils have the idea that art is drawn/painted on the paper and have realistic colours. Through this introduction, it was observed that some of the pupils were inspired and showed more risk taking in their art.

\section{Broader and Deeper Understanding of Art}

- They were inspired to want to make their art meaningful and not just beautiful - art is not just drawing and colouring and making things aesthetically pleasing.

- It may be possible to integrate Art and other subjects so pupils do not see knowledge in isolation...Many of them see realism as the only form of Art

- Art is not confined to just drawing and painting. It is about interaction with the materials and environment.

- Pupils did not know the existence of such art forms previously and they now have a better idea of the various genres of art.

- It opens up their minds and sets them to relook at what art is. They are still very trapped and holed-in when it comes to perception of art.

- Students are inspired by the contemporary artworks and they are convinced that art is not about the end-product. They have a better understanding on the importance of concept prior to the chain of processes leading to their final artwork. Most importantly, students must be able to articulate "why they do what they do" and the importance of how they arrived at their final presentation. 


\section{Higher-Order Thinking Skills: Increased Capacity to Analyze, Evaluate and Create}

- I think pupils will understand that art is not only about showing off techniques and skills, but the experience the artist wants his viewers to have experience while viewing his artwork.

They will also learn to look at spaces differently and see the potential of every space on how they could use their environment to create a total arts experience for their viewers.

- They become more observant and sensitive to pick up visual cues such as colours and the lack of colours and facial expressions of people in the art work. They learn to consider questions such as 'what if the art work was installed a different way?'

- Contemporary art is a powerful platform to relate to the students that art is not about creating beautiful art pieces that are aesthetically pleasing to the eyes or 'copied art' that are almost identical to the artwork by the established artists but rather, a powerful visual impact of a strong intent in bringing awareness to the target audience of what the artist has synthesized from his/her life experiences prior to the creation of the final art form.

When contemporary art is introduced to students, several outcomes were observed.

Engaged Learners: According to these teacher remarks, students have become more vocal and "engaged in the discussions". They were also curious to learn more, as observed, "Some came up to ask more questions and jotted down names and keywords so that they could go back home to do more research". This shows that their learning continued outside of the classroom, that they were inspired to investigate and to become self-directed learners.

Freedom of Expression and Empathy through Art: As observed, "the open discussions have helped to broaden the views" of the students in art, and empowered with this newly acquired visual literacy skills, "they have learned to express their views and not be afraid to say them and then justify them with reasons". They were also more empathetic and "receptive to their peers" artwork and they (are) willing to try to see from the perception of an artist's view". Students were observed to be more aware of the artists' intent while creating artworks and therefore would suspend judgment and instant criticisms when looking at art.

No Limit to Creativity: With a better understanding of contemporary art/art as a whole, students become open to different opinions, as mentioned, "they also realized there is no right or wrong answer" and "there's no limit to creativity" They also feel they can be as creative and imaginative as they want to be and were more empowered as artists as they "showed more risk taking in their art (making)". 
Broader and Deeper Understanding of Art: Students were observed to have a broader and deeper understanding of art. "Inspired by the contemporary artworks...they are convinced that art is not about the end-product", they became more aware of the concept behind artworks, the process of art-making and the articulation of ideas within an artwork. Students were amazed and could not quite understand that art can be so "extreme and abstract" and were thus inspired to "make their art meaningful and not just beautiful".

Higher-Order Thinking Skills: Increased Capacity to Analyze, Evaluate and Create: Students were noticed to have "become more observant and sensitive to...visual cues such as colours...facial expressions of people in the art work" Other than art making, they would also consider the difference in how artworks are installed and how that would affect the artwork and subsequently, the reading of the artwork.

They were also observed to be able to differentiate between showing off technical skills in art making and creating an "experience the artist wants his viewers to experience while viewing his artwork." Their ability to analyze artwork, evaluate the potential and suitability of spaces for the artwork to eventually create "a total arts experience for their viewers" was observed to have increased with the introduction of contemporary art in their curriculum.

\section{Empowerment}

Contemporary art is a powerful platform to relate to the students that art is not about creating beautiful art pieces that are simply aesthetically pleasing to the eyes or about 'copied art' that is almost identical to the artwork by established artists but rather, a powerful visual impact of a strong intent in bringing awareness to the target audience of what the artist has synthesized from his/her life experiences (survey response).

Although 13 respondents is a small sample to draw a conclusion, results seem to indicate that teaching contemporary art in primary art classrooms promotes critical thinking and creativity rather than merely skill based rote learning. Survey responses suggest that teaching contemporary art encourages learner engagement, freedom of expression, empathy, risk taking in art making, a broader and deeper understanding in art and that it fosters higher-order thinking skills by increasing students' opportunity in analyzing and evaluating art through art discussions and in creating/making original works of art. These skills can be used as a powerful tool that can give voice to children and youth who are so often not given a voice, thus suggesting the significance of including contemporary art theory and practice in the primary school curriculum.

The way art is taught in primary schools can be adapted to accommodate contemporary art making practices. In order to successfully change the way art is being taught in schools, the art teachers should first of all be equipped with 
an understanding of contemporary art. The modes of art assessment also need to be revised, this is one area where further research into adapting assessment models to better encompass contemporary approaches in art making and thinking could be pursued. Study of the pedagogy involved in teaching topics such as Conceptual art and Installation art is another area that can help both teachers and students understand the power of questioning and the dynamics of space. These preliminary viewpoints from teachers in the field seem to indicate that allowing students to inhabit and change the literal and the conceptual classroom space empowers them and translates into self-directed learning and exploration.

\section{Appendix}

Survey:

Research Topic: Introducing Contemporary Art in Primary Schools

By Twardzik Ching Chor Leng

Name:

Years of experience teaching in Primary school:

Kindly answer the following questions

1. When did you attend the Advance diploma course in NIE?

2. How did you feel about Contemporary Art before embarking on the Advance Diploma course?

3. How did you feel about Contemporary Art after the Advance Diploma course?

4. What did you learn with regards to Contemporary art? You can talk about Installation Art, Land Art, Conceptual Art, Contemporary Art ideas/theories/ artists.

5. Have you introduced any of the above topics to your students in school? Yes/No

6. How did you introduce the topic of Contemporary Art to your students? Is it through hands on art making sessions, field trips, slide presentations or otherwise? Please give specific examples if any.

7. Did those art lessons benefit your students? How? Please give specific examples if any.

i) Were students intrigued by the artworks and were they curious to learn more? Yes/No

ii) Did students have a better understanding of contemporary art/art as a whole as they are enabled with visual literacy skills? Yes/No

iii) Are students more independent and self-assured when making art as they understand what art is and why they make art? Yes/No

iv) Did students feel they can be as creative and imaginative as they want to be and were empowered as artists? Yes/No

v) Any other benefits?

How did teaching them to make contemporary art/introducing them to contemporary art benefit the students? Please give specific examples if any. 


\section{Acknowledgments}

My sincere thanks to all survey respondents.

\section{References}

Adams, J., 2010. Risky choices: the dilemmas of introducing contemporary art practices into schools. British Journal of Sociology of Education, 31 (6), pp. 683701.

Cheo, C, \& Millan, K.J., 2012. Mapping Research in Visual Arts Education in Singapore. UNESCO-NIE Centre for Arts Research in Education National Institute of Education, Singapore, 10(2), p.20.

Gallavan, N.P., Webster-Smith, A., \& Dean, S.S., 2012. Connecting Content, Context, and Communication in a Sixth-Grade Social Studies Class through Political Cartoons. The Social Studies, 103(5), pp.188-191.

Godfrey, T., 1998. Conceptual Art. London: Phaidon.

Hall, C., P. Thomson, \& Russell, L., 2007. Teaching like an artist: The pedagogic identities and practices of artists in schools. British Journal of Sociology of Education, 28(5), pp.605-19.

National Institute of Education, n.d. Advanced Diploma in Primary Art Education. [online] Available from: http://www.nie.edu.sg/studynie/professional-developme nt-courses/programmes-courses/advanced-diploma-programmes/advanced-d-6 [Accessed 20 May 2014]

Robinson, K., 2006. Do schools kill creativity? [Online] Available from: http://blog. ted.com/2006/06/27/sir_ken_robinso/ [Accessed: 20 May 2014]

Singapore Ministry of Education, Curriculum Planning and Development Division (CPDD), 2008. Art Syllabus: Primary and Lower Secondary. Singapore: MOE. 
